\title{
THE EFFECT OF GLUCAGON ON CARBOHYDRATE METABOLISM IN NORMAL HUMAN BEINGS ${ }^{1}$
}

\author{
By PHILIP K. BONDY AND LEO R. CARDILLO 2 \\ (From the Department of Internal Medicine, Yale University School of Medicine, \\ New Haven, Conn.)
}

(Submitted for publication October 20, 1955; accepted January 9, 1956)

Since the isolation of glucagon (hyperglycemicglycogenolytic factor, HGF) from the pancreas $(1,2)$, and the demonstration that it is released in appreciable amounts into the blood stream (3-5), there has been much speculation about the possibility that diabetes mellitus may result from an imbalance between secretion of insulin and glucagon (6-8). This speculation has been given additional weight by the demonstration that anterior pituitary growth hormone, a well established diabetogenic agent, causes release of a glucagonlike substance from the pancreas of experimental animals (5). The present investigation was undertaken to discover whether glucagon could produce an elevated blood glucose concentration with inhibition of glucose utilization, since this combination is usually observed in diabetic patients (9-11). These studies confirm and extend previous observations (12) that glucagon does not interfere with the uptake of glucose by the peripheral tissues.

\section{METHODS}

Arterial and venous samples were obtained from Cournand needles inserted into the antecubital vein and brachial artery after local infiltration with Procaine, without epinephrine. After allowing several minutes to elapse, samples were removed from artery and vein simultaneously. The interval between arterial and venous samples was never greater than thirty seconds.

Blood samples for glucose analysis were collected in fluoride-oxalate and deproteinated within a few minutes. Glucose was determined in quadruplicate by the Nelson modification of the Somogyi technique (13), using the specific precautions previously described to insure maximum reproducibility (14).

Serum inorganic phosphorus determinations were made

1 This investigation was supported by a research grant A-245 (C-3) from the National Institute of Arthritis and Metabolic Diseases of the National Institutes of Health, U. S. Public Health Service.

2 This work represents a portion of the material presented in satisfaction of the thesis requirement for the M.D. degree at the Yale University School of Medicine. on venous samples according to the method of Fiske and Subbarow (15).

Alpha amino nitrogen content of plasma and whole blood was determined on venous samples according to the method of Frame, Russell, and Wilhelmi $(16,17)$.

The concentration of blood ketone bodies was determined on arterial samples by a modification (18) of the method of Greenberg and Lester (19).

In acute experiments, three control pairs of arteriovenous samples were drawn and then $1.0 \mathrm{ml}$. (0.95 mg.) of glucagon ${ }^{3}$ was immediately injected through the venous Cournand needle. Samples were taken 1, 2, 3, 5, 7, 10 , and 15 minutes after the injection. A control experiment was run in two cases, by repeating the entire procedure, substituting a slow intravenous drip of 5 per cent glucose in water for glucagon. The rate of administration of glucose was adjusted to produce an arterial glucose curve approximating that produced by glucagon. The control experiments followed the glucagon experiments by at least one week.

The effect of HGF on the peripheral circulation was studied by following skin temperatures and finger plethysmographs in two volunteers for fifteen minutes after the injection of glucagon. The subjects rested in a constant temperature room at 82 degrees F. for twentyfour minutes before the injections. Skin temperatures were measured in seven locations by thermocouples; relative blood flow was estimated by finger plethysmography, using the technique of Burch (20). No blood chemical determinations were made in these subjects.

In a second group of subjects, $0.04 \mathrm{mg}$. per $\mathrm{Kg}$. of glucagon was administered in 240 to $300 \mathrm{ml}$. of 0.9 per cent saline intravenously at a constant rate over the course of two hours. Control arterial and venous samples were drawn five minutes before and at the start of the glucagon infusion, and $15,30,60$, and 120 minutes thereafter, while the glucagon was being administered. In

3 The glucagon preparation employed in these experiments, kindly supplied by Dr. W. R. Kirtley, was Lilly Lot number $208-158 \mathrm{~B}-214$, containing $0.95 \mathrm{mg}$. per $\mathrm{ml}$. of protein in insulin diluting fluid. The glucagon was approximately 50 per cent pure, based on the potency of crystalline glucagon ( 0.2 microgram per kilogram of body weight, injected intravenously into anesthetized cats, causes a maximum blood sugar rise of 30 to 40 milligrams per cent, ten to fifteen minutes after injection). The insulin content was between 0.005 and 0.05 units per ml. of solution. 
some instances another venous sample was drawn after the completion of the infusion.

A third group of subjects received 200 to $300 \mathrm{ml}$. of 5 per cent glucose by slow intravenous injection instead of glucagon. Conditions of this experiment were identical to those of the second group, except that only venous samples were drawn.

In most experiments of the latter two groups, hematocrit determinations were made before and after the infusions.

All subjects were adult males who had been eating a diet containing at least $250 \mathrm{gm}$. of carbohydrate daily. They were either entirely well or in late convalescence and in none was there evidence or history of any disorder of carbohydrate metabolism. Experiments were run in the early morning, with all patients in the postabsorptive state.

\section{RESULTS}

In the acute group (Table IA), the arterial glucose concentration began to rise within one minute after the injection of glucagon in four of the six subjects, and in a fifth the rise became apparent within four minutes. In one subject (W. P.) glucagon produced no change.

The concentration of glucose in the vein began to rise at almost the same time as in the artery, but the rise was somewhat less steep, so that in most instances there was a pronounced increase of arterio-venous difference within two to five minutes. By ten minutes there was a highly significant $(\mathrm{p}<.01)$ rise of the mean $\mathrm{A}-\mathrm{V}$ glucose difference, and this was sustained throughout the experiment. There was no increase of $\mathrm{A}-\mathrm{V}$ glucose difference in the single subject whose arterial glucose concentration failed to rise.

When glucose was given intravenously (Table IB), the arterial concentration rose gradually, and the arterio-venous glucose also increased, in a manner indistinguishable from that seen after glucagon.

TABLE I

A. Acute effect of glucagon on the arterial and venous glucose concentration of human beings

\begin{tabular}{|c|c|c|c|c|c|c|c|c|c|c|c|c|c|c|c|c|c|c|}
\hline \multicolumn{4}{|c|}{$\begin{array}{l}\text { Name } \ldots \ldots \ldots \ldots R_{\text {. F. }} \\
\text { Age..............27 } \\
\text { Clinical status. Mentally } \\
\text { defective }\end{array}$} & \multirow{2}{*}{\multicolumn{3}{|c|}{ 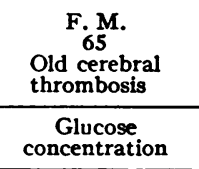 }} & \multirow{2}{*}{\multicolumn{3}{|c|}{$\begin{array}{c}\begin{array}{c}\text { W. P. } \\
63 \\
\text { Old cerebral } \\
\text { thrombosis }\end{array} \\
\begin{array}{c}\text { Glucose } \\
\text { concentration }\end{array}\end{array}$}} & \multirow{2}{*}{\multicolumn{3}{|c|}{$\begin{array}{c}\begin{array}{c}\text { F. K. } \\
25 \\
\text { Normal }\end{array} \\
\begin{array}{c}\text { Glucose } \\
\text { concentration }\end{array}\end{array}$}} & \multirow{2}{*}{\multicolumn{3}{|c|}{$\begin{array}{c}\begin{array}{c}\text { E. K. } \\
\mathbf{7 4} \\
\text { Old cerebral } \\
\text { thrombosis }\end{array} \\
\begin{array}{c}\text { Glucose } \\
\text { concentration }\end{array}\end{array}$}} & \multirow{2}{*}{\multicolumn{3}{|c|}{ 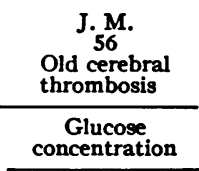 }} \\
\hline \multirow{2}{*}{$\begin{array}{c}\text { Minutes } \\
\text { after } \\
\text { glucagon }\end{array}$} & \multicolumn{3}{|c|}{$\begin{array}{c}\text { Glucose } \\
\text { concentration }\end{array}$} & & & & & & & & & & & & & & & \\
\hline & Art. & Ven. & A-V & Art. & Ven. & A-V & Art. & Ven. & A-V & Art. & Ven. & A-V & Art. & Ven. & A-V & Art. & Ven. & A-V \\
\hline $\begin{array}{r}-4 \\
-2 \\
0 \\
1 \\
2 \\
3 \\
5 \\
7 \\
10 \\
15\end{array}$ & $\begin{array}{r}m \\
81 \\
84 \\
84 \\
92 \\
88 \\
88 \\
106 \\
120 \\
137 \\
154\end{array}$ & $\begin{array}{r}1100 \\
79 \\
79 \\
79 \\
81 \\
84 \\
89 \\
94 \\
101 \\
119 \\
131\end{array}$ & $\begin{array}{r}\text { nl. } \\
2 \\
5 \\
5 \\
11 \\
4 \\
-1 \\
12 \\
19 \\
18 \\
23\end{array}$ & $\begin{array}{c}\text { mg } \\
66 \\
68 \\
70 \\
74 \\
90 \\
91 \\
101 \\
111 \\
117 \\
115\end{array}$ & $\begin{array}{r}.100 \mathrm{~m} \\
57 \\
66 \\
69 \\
70 \\
76 \\
80 \\
94 \\
98 \\
103 \\
110\end{array}$ & $\begin{array}{r}\text { al. } \\
9 \\
2 \\
1 \\
4 \\
14 \\
11 \\
7 \\
13 \\
14 \\
5\end{array}$ & $\begin{array}{l}m 8 \\
69 \\
69 \\
72 \\
65 \\
74 \\
71 \\
74 \\
77 \\
77 \\
72\end{array}$ & $\begin{array}{c}/ 100 \\
64 \\
62 \\
69 \\
68 \\
69 \\
69 \\
71 \\
76 \\
74 \\
71\end{array}$ & $\begin{array}{r}l . \\
5 \\
7 \\
3 \\
-3 \\
5 \\
2 \\
3 \\
1 \\
3 \\
1\end{array}$ & $\begin{array}{r}m g \\
69 \\
78 \\
74 \\
79 \\
89 \\
88 \\
101 \\
111 \\
116 \\
118\end{array}$ & $\begin{array}{r}1100 \mathrm{~m} \\
63 \\
74 \\
70 \\
73 \\
82 \\
85 \\
90 \\
97 \\
103 \\
105\end{array}$ & $\begin{array}{r}\text { nl. } \\
6 \\
4 \\
4 \\
6 \\
7 \\
3 \\
11 \\
14 \\
13 \\
13\end{array}$ & $\begin{array}{c}\text { mg } \\
74 \\
77 \\
76 \\
74 \\
75 \\
77 \\
87 \\
92 \\
96 \\
\text { No }\end{array}$ & $\begin{array}{c}. / 100 n \\
66 \\
72 \\
68 \\
71 \\
72 \\
71 \\
77 \\
81 \\
83 \\
0\end{array}$ & $\begin{array}{r}\text { ml. } \\
8 \\
5 \\
8 \\
3 \\
3 \\
6 \\
10 \\
11 \\
13\end{array}$ & $\begin{array}{r}m \\
81 \\
87 \\
87 \\
89 \\
99 \\
102 \\
107 \\
117 \\
120 \\
146\end{array}$ & $\begin{array}{r}.100 \\
87 \\
86 \\
85 \\
83 \\
87 \\
96 \\
100 \\
116 \\
115 \\
134\end{array}$ & $\begin{array}{r}\text { nl. } \\
-6 \\
1 \\
2 \\
6 \\
12 \\
6 \\
7 \\
1 \\
5 \\
12\end{array}$ \\
\hline
\end{tabular}

B. Effect of glucose on the arterial and venous glucose concentration

\begin{tabular}{|c|c|c|c|c|c|c|}
\hline \multicolumn{4}{|c|}{ 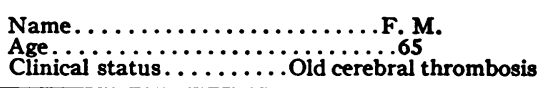 } & \multirow{2}{*}{\multicolumn{3}{|c|}{$\begin{array}{c}\begin{array}{c}\text { F. K. } \\
25 \\
\text { Normal }\end{array} \\
\begin{array}{c}\text { Glucose } \\
\text { concentration }\end{array}\end{array}$}} \\
\hline \multirow{2}{*}{$\begin{array}{l}\text { Minutes } \\
\text { after } \\
\text { glucose }\end{array}$} & \multicolumn{3}{|c|}{$\begin{array}{c}\text { Glucose } \\
\text { concentration }\end{array}$} & & & \\
\hline & Art. & Ven. & $\overline{A-V}$ & Art. & Ven. & A-V \\
\hline $\begin{array}{r}-4 \\
-2 \\
0 \\
1 \\
2 \\
3 \\
5 \\
7 \\
10 \\
15\end{array}$ & $\begin{array}{r}96 \\
85 \\
104 \\
111 \\
114 \\
120 \\
123 \\
130 \\
139 \\
141\end{array}$ & $\begin{array}{r}1100 \\
91 \\
82 \\
83 \\
102 \\
103 \\
104 \\
110 \\
113 \\
114 \\
119\end{array}$ & $\begin{array}{r}5 \\
3 \\
21 \\
9 \\
11 \\
16 \\
13 \\
17 \\
25 \\
22\end{array}$ & $\begin{array}{r}96 \\
98 \\
96 \\
96 \\
103 \\
106 \\
107 \\
112 \\
115 \\
125\end{array}$ & $\begin{array}{r}.1100 n \\
88 \\
87 \\
91 \\
88 \\
93 \\
96 \\
101 \\
107 \\
107 \\
113\end{array}$ & $\begin{array}{r}8 \\
11 \\
5 \\
8 \\
10 \\
10 \\
6 \\
5 \\
8 \\
12\end{array}$ \\
\hline
\end{tabular}


TABLE II

Effect of two-hour intravenous infusions of HGF on the arterial and venous glucose concentration (mg. per $100 \mathrm{ml}$.)

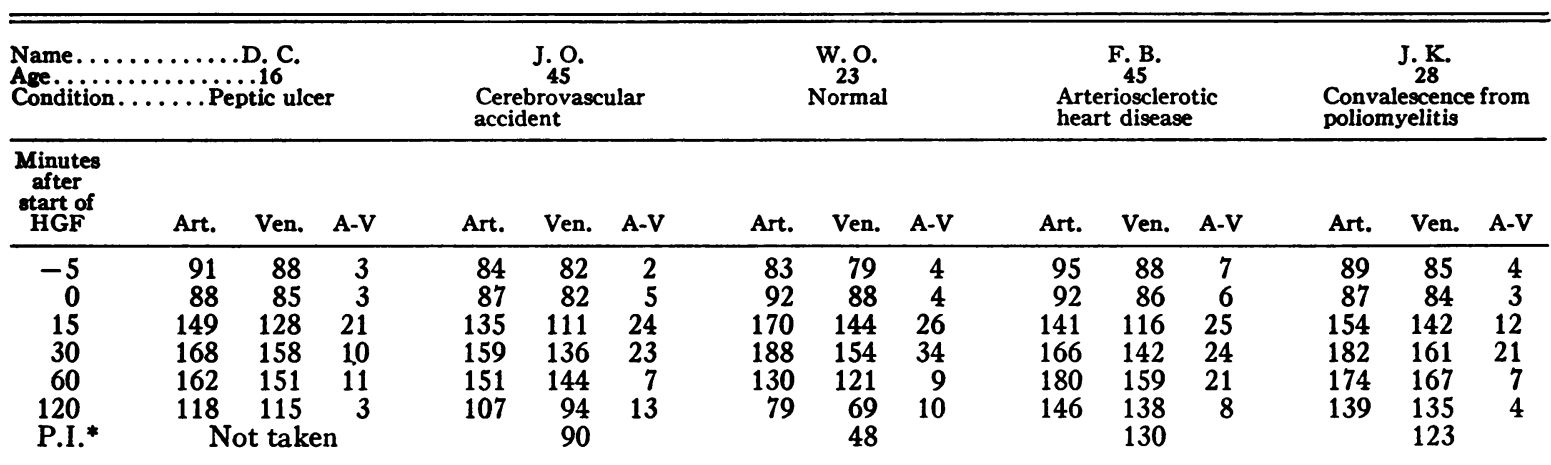

* Post infusion venous glucose determination, drawn within $10 \mathrm{~min}$. after HGF. "Hypoglycemic" reactions were noted in subjects D. C., W. O., F. B., and J. K.

There were no significant changes in peripheral blood flow following acute glucagon injection.

A rapid rise of arterial and venous blood glucose levels with an accompanying increased arteriovenous difference occurred during the two-hour glucagon infusions (Table II). In all instances a later decrease in glucose levels occurred while HGF was still being administered. Indeed in four of the five subjects clinical hypoglycemic reactions were noticed 110 to 120 minutes after the beginning of the infusions. Post-infusion venous glucose levels, in these four cases, demonstrated a continuing fall in all instances and definite hypoglycemia in one instance. Intravenous glucose eliminated or ameliorated the reaction.

Venous blood sugar curves varied considerably in the subjects to whom glucose was administered over two hours. In three, a peak was reached at one-half or one hour, and there was a decline of 10 to $208 \mathrm{mg}$. per cent during the second hour, but in two others, levels continued to rise throughout the infusion.

The arterial glucose concentration was compared with the $\mathrm{A}-\mathrm{V}$ difference for the acute HGF groups

TABLE III

Serum inorganic phosphorus levels (mg. per cent) during HGF and glucose infusions

\begin{tabular}{|c|c|c|c|c|c|c|c|c|c|}
\hline \multirow[b]{2}{*}{$\begin{array}{l}\text { Name } . \ldots \ldots \ldots \\
\text { Age............. }\end{array}$} & \multicolumn{5}{|c|}{ HGF } & \multicolumn{4}{|c|}{ Glucose } \\
\hline & . D. ${ }_{16}$. & J. 0. & $\mathrm{w}_{23} \mathrm{O}$. & F. $B$. & J. K. & w. 0. & J. ${ }_{66}^{H}$. & J.M. & $\mathrm{W}_{\mathbf{2 1}} \mathbf{G}$. \\
\hline \multicolumn{10}{|l|}{$\begin{array}{c}\text { Minutes } \\
\text { after start } \\
\text { of } \mathrm{HGF}\end{array}$} \\
\hline $\begin{array}{c}-5 \\
0 \\
15 \\
30 \\
60 \\
120 \\
\text { Max. decrease } \\
\text { Max. decrease \% }\end{array}$ & $\begin{array}{l}4.30 \\
4.40 \\
3.60 \\
3.10 \\
2.77 \\
2.96 \\
1.63 \\
37.0\end{array}$ & $\begin{array}{l}3.69 \\
3.61 \\
2.82 \\
2.81 \\
2.67 \\
2.56 \\
1.05 \\
29.1\end{array}$ & $\begin{array}{r}3.47 \\
3.44 \\
3.28 \\
3.23 \\
3.13 \\
3.05 \\
.39 \\
11.4\end{array}$ & $\begin{array}{c}2.96 \\
2.84 \\
2.64 \\
2.59 \\
2.53 \\
2.36 \\
.48 \\
16.9\end{array}$ & $\begin{array}{r}4.47 \\
4.55 \\
4.27 \\
4.14 \\
3.97 \\
3.86 \\
.69 \\
15.2\end{array}$ & $\begin{array}{l}4.45 \\
4.34 \\
4.30 \\
4.22 \\
4.15 \\
4.07 \\
.27 \\
6.2\end{array}$ & $\begin{array}{l}3.15 \\
3.11 \\
3.03 \\
2.94 \\
2.86 \\
2.78 \\
.33 \\
10.6\end{array}$ & $\begin{array}{r}3.67 \\
3.57 \\
3.48 \\
3.40 \\
3.27 \\
3.16 \\
.41 \\
11.5\end{array}$ & $\begin{array}{r}4.44 \\
4.12 \\
3.83 \\
3.70 \\
3.54 \\
.90 \\
20.3\end{array}$ \\
\hline
\end{tabular}

Effect of two-hour HGF intravenous infusions on blood ketones (mg. per cent acetone)

\begin{tabular}{rlll}
\hline \multicolumn{4}{c}{ HGF } \\
\hline-5 & 1.32 & 0.23 & 0.56 \\
0 & 0.84 & 0.47 & \\
15 & 1.46 & 0.29 & \\
30 & 1.04 & 0.82 & \\
60 & 0.44 & 0.00 & 0.77 \\
120 & 2.02 & 0.41 & 0.7
\end{tabular}


GLUCAGON AND CARBOHYDRATE METABOLISM IN MAN

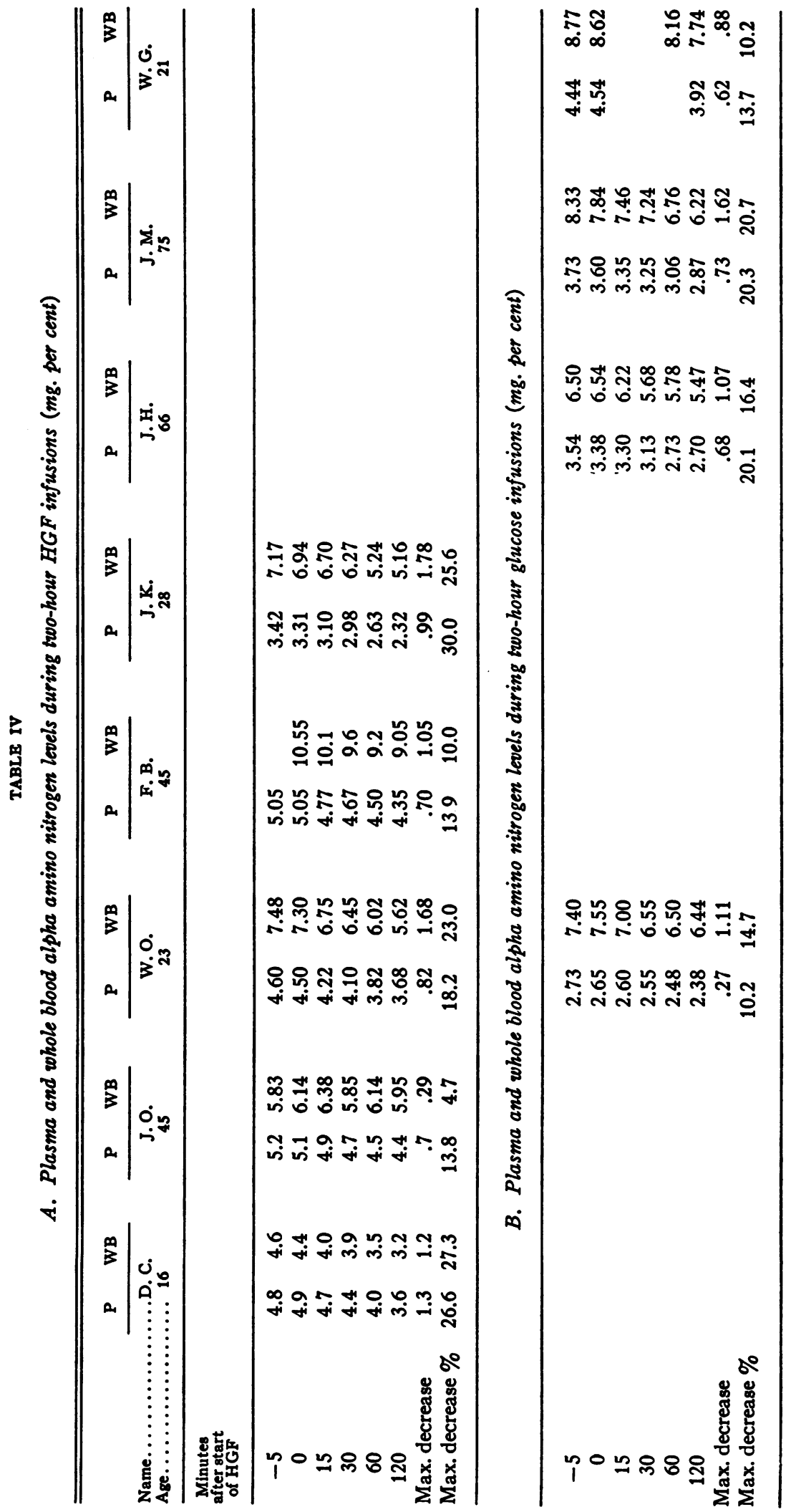


and for the two patients in whom $\mathrm{A}-\mathrm{V}$ differences were determined after acute glucose administration. The slopes of the lines of the HGF ( $b=$ $.25)$ and glucose $(b=.31)$ groups were very similar $(\mathrm{p}=.40)$.

Serum phosphate levels declined in every case during HGF or glucose infusions (Table III). In both groups there was a similar gradual decrease with the lowest value at the end of the infusion (D.C. of the HGF group was an exception). The average percentage of maximum decrease during the infusions was $21.9 \pm 9.7$ per cent $^{4}$ in the HGF group and $12.4 \pm 5.3$ per cent in the glucose group.

Whole blood and plasma levels of alpha amino nitrogen showed a similar progressive decrease during HGF and glucose infusions (Table IV). The average percentages of maximum decrease noted were : $18.1 \pm 10.0$ per cent and $20.5 \pm 7.5$ per cent in the HGF group, and $15.5 \pm 4.5$ per cent and $16.1 \pm 4.9$ per cent in the glucose group, for whole blood and plasma levels, respectively.

Ketone body levels were determined in three of the subjects infused with HGF (Table III). The levels were not elevated initially and no significant changes were noted during the course of the infusions.

Hematocrit levels before and after infusions were determined in all subjects of the HGF group and in two of the glucose group. In no instance was there a change exceeding 1 per cent.

\section{DISCUSSION}

The fact that glucagon raises the blood glucose concentration has led a number of authors to suggest that it may be diabetogenic $(6-8)$. Transient hyperglycemia, however, is not diabetes. In order to prove that a substance is truly diabetogenic it is necessary to show that, in addition to raising the blood glucose concentration, it also inhibits glucose utilization, either absolutely or relative to the arterial glucose concentration, or that it causes major dislocations of the metabolic pattern associated with hyperglycemia, such as ketonemia or acidosis. The present experiments were designed to determine whether the action of glucagon meets any of these criteria of a true diabetogenic agent.

4 Throughout this communication, statistical variability is expressed as the standard deviation.
The simplest and most convincing evidence of altered glucose utilization is an actual change of peripheral glucose oxidation. We were unable to investigate this question directly. Good indirect evidence can be obtained from the arteriovenous glucose concentrations provided that no changes of peripheral blood flow occur simultaneously. We established that glucagon (unlike epinephrine) has no effect on peripheral blood flow. The arterio-venous glucose differences measured in these experiments are, therefore, direct reflections of alterations of peripheral glucose utilization (including entry into cells, phosphorylation, glycogen formation, and oxidation to pyruvate or lactate or to carbon dioxide). The validity of the arterio-venous glucose difference as an index of carbohydrate utilization is well established $(9,21$, 22). In our studies, both intravenous glucose and glucagon raised the arterial blood glucose level and increased the arterio-venous difference in a parallel fashion. The relationship between arterial blood glucose concentration and arterio-venous difference after glucagon was the same as after glucose and closely resembles that found by Somogyi after oral glucose (21). No evidence whatever could be found to indicate that glucagon reduced peripheral glucose utilization in these experiments. These findings are like those of Van Itallie, Morgan, and Dotti (12), who gave similar doses of HGF in saline infusions during one-half hour periods to normal subjects in the post-absorptive state. They also noted a hyperglycemic effect with increased arterio (capillary)venous glucose differences. When $A-V$ differences after glucose administration were compared to those after HGF, their work suggested that HGF may have enhanced glucose utilization slightly.

A somewhat less specific index of glucose utilization is the change in serum inorganic phosphate after the administration of a test substance. There is abundant evidence that the administration of glucose or insulin to normal animals and human beings causes a decreased level of blood and serum inorganic phosphorus (23-26) and that this response is usually diminished or absent in diabetics $(23,24,26)$. This response seems to be a function of the disappearance of hexose from the blood $(23,24,27,28)$. In our experiments, the serum inorganic phosphate fell at least as rapidly and as 
far after glucagon as it did after glucose. Kirtley, Waife, Helmer, and Peck (29) also produced a fall of serum phosphate in normal subjects given glucagon. These observations do not support the concept that glucagon interferes with glucose utilization.

In our experiments, the plasma and whole-blood alpha-amino nitrogen fell during glucagon administration. This effect has little specific bearing on the rate of glucose utilization, but it is similar to the changes seen when glucose utilization is increased after the administration of glucose or insulin. Although glucagon reduced plasma amino nitrogen in normal human beings, growth hormone (claimed by some to act by causing a release of glucagon) had no such effect (30).

The administration of glucagon failed to alter the blood ketone body level, although the liver glycogen was probably greatly depleted toward the end of the two-hour infusion of HGF. In this respect also, glucagon differs from the growth hormone preparations $(30,31)$.

During the prolonged HGF infusions, the arterial glucose concentration uniformly reached a peak at 1 hour and then declined, often to such low levels or at so great a speed as to produce hypoglycemic symptoms. The falling phase probably represents a combination of two factors. The hyperglycemia provokes an increased secretion of insulin $(4,32,33)$ so that disposal of the glucose into the peripheral tissues is accelerated $(34,35)$. This effect is illustrated in our patients (J. H., W. G.) who received glucose alone and whose glucose concentration began to drop while the glucose injection was continuing. Since little of the glucose entering the tissues is later released as glycogen precursors (29) the liver glycogen falls steadily. In this respect, glucagon is quite different from epinephrine which promotes the release of lactate from the muscles, and inhibits the peripheral utilization of glucose, thus permitting the maintenance of a normal liver glycogen level $(12,36)$. As a result of these two factors, liver glycogen becomes inadequate and the release of glucose from the liver falls behind the rate of peripheral disposal. To test this hypothesis, a second large dose of glucagon (.95 mg. I.V.) was given suddenly to a subject whose arterial glucose level was falling during HGF infusion.
The second dose of glucagon did not halt or reverse the falling glucose level.

The late hypoglycemic effect of glucagon is not caused by the small amount of insulin it contains, since the total amount of insulin received by our subjects could not have exceeded 1 unit in 2 hours, or .05 units in a single injection. Moreover, the late hypoglycemia can be produced simply by injecting glucose alone, without exogenous insulin.

Our finding that glucagon does not interfere with the peripheral utilization of glucose in human beings is in agreement with most of the studies of other investigators using animals as subjects (37-39).

Although there is no evidence that glucagon can reduce glucose utilization in vivo, it apparently can reduce the glycogenic effect of insulin on diaphragm muscle in vitro $(40,41)$. The glycogen metabolism of the diaphragm, however, is not characteristic of other voluntary muscle (42), and the pertinence of studies of such special tissues as diaphragm to the over-all body metabolism is not clear.

\section{SUMMARY AND CONCLUSIONS}

Glucagon (pancreatic hyperglycemic-glycogenolytic factor) was given intravenously to normal human subjects. Acutely, it produced a rapid rise of arterial and venous blood glucose concentrations, with increased arterio-venous glucose differences. No change in peripheral blood flow occurred.

When given by constant intravenous infusion for two hours, glucagon caused a rise of both arterial and venous glucose concentrations with increasing arterio-venous glucose differences, until about 1 hour, after which the arterial glucose level fell. Toward the end of the test period hypoglycemic symptoms often occurred. The falling glucose concentration could not be prevented by larger doses of glucagon.

Over the two-hour period serum inorganic phosphate and plasma and whole blood alpha amino nitrogen concentrations fell steadily. There was no change in blood ketone body concentration. In all respects, the effects of HGF were similar to those of doses of glucose which produced comparable arterial glucose concentration curves, and different from those of growth hormone.

These observations give no support to the con- 
cept that glucagon is diabetogenic, since no evidence was obtained of reduced glucose utilization. It is more likely that, in the intact organism, glucagon works synergistically with insulin to release glucose from the liver, thus making it available for the peripheral utilization which is promoted by insulin.

\section{Addendum}

Elrick, Hlad, and Witten (43) have recently found that the A-V glucose difference after glucagon is greater than during comparable hyperglycemia produced by glucose alone. These findings are somewhat at variance with ours, but the difference may reflect the fact that in Elrick, Hlad, and Witten's studies the patients were heavily loaded with glucose before the administration of glucagon. In any case, no eivdence of inhibition of glucose utilization was found.

\section{ACKNOWLEDGMENTS}

The authors are grateful to Dr. William E. Lattanzi who performed the blood ketone body determinations, to Miss Pauline DelMonaco for the measurement of skin temperatures and blood flows, and to Mrs. Diana Hengerer for her general technical assistance.

\section{REFERENCES}

1. Sutherland, E. W., Cori, C. F., Haynes, R., and Olsen, N. S., Purification of the hyperglycemic-glycogenolytic factor from insulin and from gastric mucosa. J. Biol. Chem., 1949, 180, 825.

2. Staub, A., Sinn, L., and Behrens, O. K., Purification and crystallization of hyperglycemic-glycogenolytic factor (HGF). Science, 1953, 117, 628.

3. Foà, P. P., Santamaria, L., Weinstein, H. R., Berger, S., and Smith, J. A., Secretion of the hyperglycemic-glycogenolytic factor in normal dogs. Am. J. Physiol., 1952, 171, 32.

4. Foà, P. P., Weinstein, H. R., and Smith, J. A., Secretion of insulin and of a hyperglycemic substance studied by means of pancreatic-femoral cross-circulation experiments. Am. J. Physiol., 1949, 157, 197.

5. Bornstein, J., Reid, E., and Young, F. G., The hyperglycaemic action of blood from animals treated with growth hormone. Nature, 1951, 168, 903.

6. Ferner, H., The A- and B-cells of the pancreatic islets as sources of the antagonistic hormones glucagon and insulin. The shift of the AB-relation in diabetes mellitus. Am. J. Digest. Dis., 1953, 20, 301.

7. DeDuve, C., Glucagon, the hyperglycaemic-glycogenolytic factor of the pancreas. Lancet, 1953, 2, 99.
8. Pincus, I. J., and Rutman, J. Z., Glucagon, the hyperglycemic agent in pancreatic extracts. A possible factor in certain types of diabetes. Arch. Int. Med., 1953, 92, 666.

9. Rabinowitch, I. M., Simultaneous determinations of arterial and venous blood-sugars in diabetic individuals. Brit. J. Exper. Path., 1927, 8, 76.

10. Soskin, S., and Levine, R., A relationship between the blood sugar level and the rate of sugar utilization, affecting the theories of diabetes. Am. J. Physiol., 1937, 120, 761.

11. Searle, G. L., Strisower, E. H., and Chaikoff, I. L., Glucose pool and glucose space in the normal and diabetic dog. Am. J. Physiol., 1954, 176, 190.

12. Van Itallie, T. B., Morgan, M. C., and Dotti, L. B., Effect of glucagon on peripheral utilization of glucose in man. J. Clin. Endocrinol. \& Metab., 1955, 15, 28.

13. Nelson, N., A photometric adaptation of the Somogyi method for the determination of glucose. J. Biol. Chem., 1944, 153, 375.

14. Bondy, P. K., Spontaneous fluctuations in glucose content of the hepatic venous blood in resting normal human beings. J. Clin. Invest., 1952, 31, 231.

15. Fiske, C. H., and Subbarow, Y., The colorimetric determination of phosphorus. J. Biol. Chem., 1925, 66, 375.

16. Frame, E. G., Russell, J. A., and Wilhelmi, A. E., The colorimetric estimation of amino nitrogen in blood. J. Biol. Chem., 1943, 149, 255.

17. Russell, J. A., Note on the colorimetric determination of amino nitrogen. J. Biol. Chem., 1944, 156, 467.

18. Michaels, G. D., Margen, S., Liebert, G., and Kinsell, L. W., Studies in fat metabolism. I. The colorimetric determination of ketone bodies in biological fluids. J. Clin. Invest., 1951, 30, 1483.

19. Greenberg, L. A., and Lester, D., A micromethod for the determination of acetone and ketone bodies. J. Biol. Chem., 1944, 154, 177.

20. Burch, G. E., A new sensitive portable plethysmograph. Am. Heart J., 1947, 33, 48.

21. Somogyi, M., Studies of arteriovenous differences in blood sugar. I. Effect of alimentary hyperglycemia on the rate of extrahepatic glucose assimilation. J. Biol. Chem., 1948, 174, 189.

22. Lang, S., Goldstein, M. S., and Levine, R., Influence of the liver on uptake of glucose by extrahepatic tissues. Am. J. Physiol., 1954, 177, 447.

23. Bolliger, A., and Hartman, F. W., Observations on blood phosphates as related to carbohydrate metabolism. J. Biol. Chem., 1925, 64, 91.

24. Harrop, G. A., Jr., and Benedict, E. M., The participation of inorganic substances in carbohydrate metabolism. J. Biol. Chem., 1924, 59, 683.

25. Schneeberg, N. G., Serum inorganic phosphorus in the diagnosis of diabetes mellitus. J. Clin. Endocrinol., 1951, 11, 602.

26. Forsham, P. H., and Thorn, G. W., Changes in inorganic serum phosphorus during the intravenous 
glucose tolerance test as an adjunct to the diagnosis of early diabetes mellitus. Proc. Am. Diabetes A., 1949, 9, 99.

27. Levine, R., Loube, S. D., and Weisberg, H. F., Nature of the action of insulin on the level of serum inorganic phosphate. Am. J. Physiol., 1949, 159, 107.

28. Miller, M., Drucker, W. R., Owens, J. E., Craig, J. W., and Woodward, H., Jr., Metabolism of intravenous fructose and glucose in normal and diabetic subjects. J. Clin. Invest., 1952, 31, 115.

29. Kirtley, W. R., Waife, S. O., Helmer, O. M., and Peck, F. B., Effect of purified glucagon (hyperglycemic-glycogenolytic factor, HGF) on carbohydrate and corticoid metabolism in normal and diabetic subjects. Diabetes, 1953, 2, 345.

30. Bondy, P. K. The acute effects of purified crystalline pituitary growth hormone in normal human beings. Yale J. Biol. \& Med., 1954, 26, 263.

31. Engel, F. L., Factors involved in the ketogenic action of growth hormone in Henry Ford Hospital, Detroit. International Symposium: The Hypophyseal Growth Hormone, Nature and Actions. New York, Blakiston, 1955, p. 344.

32. Brown, E. M., Jr., Dohan, F. C., Freedman, L. R., DeMoor, P., and Lukens, F. D. W., The effects of prolonged infusion of the dog's pancreas with glucose. Endocrinology, 1952, 50, 644.

33. Bornstein, J., Normal insulin concentration in man. Australian J. Exper. Biol. \& M. Sc., 1950, 28, 93.

34. Levine, R., and Goldstein, M. S., On the mechanism of action of insulin. Rec. Prog. Hormone Res., 1955, 11, 343.
35. Hastings, A. B., Renold, A. E., and Teng, C.-T., Effects of ions and hormones on carbohydrate metabolism. Rec. Prog. Hormone Res., 1955, 11, 381.

36. Cori, C. F., and Cori, G. T., The mechanism of epinephrine action. I. The influence of epinephrine on the carbohydrate metabolism of fasting rats, with a note on new formation of carbohydrates. J. Biol. Chem., 1928, 79, 309.

37. Ingle, D. J., Nezamis, J. E., and Humphrey, L. M., Absence of hyperglycemic effect of glucagon in the eviscerate rat. Proc. Soc. Exper. Biol. \& Med., 1953, 84, 232.

38. Pincus, I. J., Komarov, S. A., Snape, W. J., and Shay, H., Hyperglycemic activity of pancreatic extracts. Am. J. Physiol., 1948, 155, 460.

39. Drury, D. R., Wick, A. N., and Sherrill, J. W., The effect of the hyperglycemic factor on the metabolism of glucose by the extrahepatic tissues. Diabetes, 1954, 3, 129.

40. R.-Candela, J. L., Inhibitory effect of pancreas extract and H-G factor on the insulin glucose uptake of the isolated diaphragm. Ciba Foundation Colloquia on Endocrinology, Conference on Hormone Factors in Carbohydrate Metabolism, 1953, 6, 233.

41. Snedecor, J. G., DeMeio, R. H., and Pincus, I. J., Reduction by glucagon of glycogen deposition effect of insulin in rat diaphragm. Proc. Soc. Exper. Biol. \& Med., 1955, 89, 396.

42. Illingworth, B. A., and Russell, J. A., The effects of growth hormone on glycogen in tissues of the rat. Endocrinology, 1951, 48, 423.

43. Elrick, H., Hlad, C. J., Jr., and Witten, T., The enhancement of peripheral glucose utilization by glucagon. J. Clin. Invest., 1955, 34, 1830. 